Макаренко Андрій Миколайович аспірант, старший викладач кафедри домедичної підготовки, Інституту державного управління та наукових досліджень 3 цивільного захисту, вул. Вишгородська, 21, м. Київ, 04074, тел.: (044) 430-82-17, e-mail: makandre1981@ukr.net, https://orcid.org/0000-0002-2930-349X

\title{
АДМІНІСТРУВАННЯ НАДАННЯ ДОМЕДИЧНОЇ ДОПОМОГИ НАСЕЛЕННЮ ЯК КОМПОНЕНТА МЕДИЧНОГО РЕАГУВАННЯ НА НАДЗВИЧАЙНІ СИТУАЦІї МИРНОГО ЧАСУ
}

Анотація. В даній статті наведено сучасний стан адміністрування особливості надання домедичної допомоги населенню як компонента медичного реагування на надзвичайні ситуації мирного часу.

Територія України має велику кількість різноманітних промислових небезпечних об'єктів, що потенційно загрожує виникненню надзвичайних ситуацій техногенного характеру з великими медико-соціальними наслідками і обумовлює значні масиви постраждалих, які потребують надання домедичної допомоги у зоні надзвичайної ситуації. Останнє є прерогативою оперативнорятувальних служб [1].

Надання домедичної допомоги рятувальниками в зоні надзвичайної ситуації техногенного характеру є основною запорукою врятування життя постраждалим. Враховуючи, що рятувальники працюють в зоні підвищеної небезпеки, то вони перші, хто надасть домедичну допомогу постраждалому, оскільки бригада екстреної медичної допомоги надає медичну допомогу тільки за межами зони надзвичайної ситуації. Тобто, рятувальники після надання домедичної допомоги та усунення невідкладних станів, які загрожують життю постраждалим, евакуюють (транспортують) їх до карети екстреної медичної допомоги.

Аналіз причин загибелі постраждалих під час надзвичайних ситуацій техногенного характеру вказує на те, що значну їх частину можна було б врятувати при своєчасному та якісному наданні домедичної допомоги. За умови застосування належних заходів самодопомоги, взаємодопомоги i навичок рятувальників в зоні НС можна зменшити показник смертності на 15-18 \%.

Рятувальники першими прибувають на місце надзвичайної ситуації, вони повинні дотримуватися єдиного порядку та принципів надання домедичної допомоги постраждалим.

Ключові слова: навчання, домедична підготовка, домедична допомога, 
рятувальники, адміністрування.

Makarenko Andrii Mykolaiovych Post-Graduate student Senior lecturer of Premedical Training Department, Institute of Public Administration and Research in Civil Protection, 21 Vyshgorodska St., Kyiv, 04074, tel.: (044) 430-82-17, e-mail: makandre1981@ukr.net, https://orcid.org/0000-0002-2930-349X

\title{
ADMINISTRATION OF PRE-MEDICAL CARE AS A COMPONENT OF MEDICAL RESPONSE TO PEACE EMERGENCY SITUATIONS
}

\begin{abstract}
This article presents the current state of administration of the features of providing pre-medical care to the population as a component of medical response to emergencies in peacetime.

The territory of Ukraine has a large number of various industrial hazardous objects, which potentially threatens the emergence of technogenic emergencies with major medical and social consequences and causes large numbers of victims in need of premedical help in the emergency zone. The latter is the prerogative of rescue services [1].

Providing pre-medical help by rescuers in the technogenic emergency zone is the main guarantee of saving the lives of victims. Taking into account that rescuers work in a high-risk zone, they are the first to provide pre-medical help to the victim, as the emergency medical team provides medical care only outside of the emergency zone. That is, rescuers, after providing pre-medical help and eliminating emergencies that threaten the lives of victims, evacuate (transport) them to the ambulance.

Analysis of the causes of death of victims during man-made emergencies indicates that a significant part of them could be saved with timely and quality pre-medical help. With proper self-help, mutual aid, and rescuer skills in the emergency zone, mortality can be reduced by $15-18 \%$.

Rescuers are the first to arrive at the scene of an emergency, they must follow the uniform procedure and principles of providing pre-medical help to victims.

Keywords: training, pre-medical training, pre-hospital help, rescuers, administration

Постановка проблеми. Щорічно у світі в результаті надзвичайних ситуацій (далі - НС) техногенного і природного характеру гине близько 2 млн. осіб, а матеріальний збиток складає 3\% валового продукту економіки усіх країн. Тому, організація ліквідації медико-санітарних наслідків НС в сучасних умовах за умов збільшення їх кількості як техногенного, так i природного характеру, $\epsilon$ актуальним питанням для більшості країн світу, зокрема й України.
\end{abstract}


Актуальність прогнозування, попередження і ліквідації наслідків НС для усієї світової спільноти безперервно зростає. Досвід багатьох країн світу [2; 3]свідчить, що в тих, де створена сучасна система реагування на НС, їх наслідки можна мінімізувати. На даний час в різних країнах світу існують різні підходи до ліквідації наслідків НС. У деяких країнах створена окрема структура - медицина катастроф [4] в інших - екстрена медична допомога (далі - ЕМД) за умов НС надається силами загальної мережі медичних закладів і підрозділів охорони здоров'я [5]. При цьому мобілізуються додаткові сили і засоби призначені для використання на випадок НС.

Особливо важливим при визначенні тактики надання домедичної допомоги (далі - ДМД) постраждалим є процес прийняття рішень, що зазвичай проходить за жорстких умов дефіциту часу. При роботі за умов НС тактика повинна бути єдино образною й визначатися загальними принципами надання ДМД на етапах медичної евакуації при великих контингентах постраждалого населення. Дотримання таких принципів в умовах НC може бути досягнуто шляхом адміністрування наданням домедичної допомоги.

Аналіз останніх досліджень і публікацій. Питання адміністрування надання рятувальниками ДМД постраждалим під час НС мирного часу розглянуті у роботах таких зарубіжних та вітчизняних вчених: П. Волянський, А. Терентєва [6], Ю. Лєрмонтова [7], Б.Адамкевич-Герод, Я.Мадовіч[8], В. Михайлов [9], О. Олійник [10], А. Пилипець, Я. Пилипець [11], К.Хоменко [12], та ін

Метою статті огляд сучасного стану адміністрування надання ДМД населенню як компонента медичного реагування на НС мирного часу.

Виклад основного матеріалу. Термінологічний словник 3 публічного управління визначає поняття адміністрування як діяльність суб'єктів управління, наділених спеціально визначеними повноваженнями, пов'язана 3 реалізацією директивних функцій щодо керівництва певними об'єктами управління, яка регламентована законами та іншими нормативно-правовими актами, а також забезпечується відповідними адміністративно-розпорядчими документами, інструкціями, регламентами та процедурами, що видаються органами управління, установами та організаціями [13].

Для забезпечення ДМД населенню адміністрування повинно включати в себе такі складові:

- нормативно-правова;

- ресурсна;

- кадрова;

- фінансово-економічна складова;

- інформаційна;

- наукова. 
Оскільки будь-яка законна діяльність на рівні держави потребує нормативноправового регулювання, саме нормативно-правової складова адміністрування ДМД населенню покликана виконати цю функцію. 3 цією метою в Україні прийнято відповідні Закони України, які визначають саме поняття та основні засади надання ДМД населенню. Для реалізації Законів України приймаються підзаконні акти - Постанови кабінету міністрів України, що визначають порядок, або яким чином будуть реалізовані ті, чи інші поняття, що визначені у законі, у нашому випадку порядок надання ДМД населенню. На реалізацію ПКМУ приймаються відомчі нормативи, накази, які безпосередньо регулюють роботу виконавців.

До нормативно-правова складової ДМД населенню відносяться такі нормативні документи:

1.1. Закон України "Про екстрену медичну допомогу" ст.1 "Визначення термінів" а саме, що таке домедична допомога та екстрена медична допомога, ст.12 цього закону визначені “Особи, які зобов’язані надавати домедичну допомогу"

1.2. Постанова Кабінету Міністрів України від 21.11.2012 № 1115 “Про затвердження порядку підготовки та підвищення кваліфікації осіб, які зобов'язані надавати домедичну допомогу"

1.3. Наказ Міністерства охорони здоров'я України від 02.03.2009 № 132 “Про організацію навчання окремих категорій немедичних працівників навичкам надання першої невідкладної медичної допомоги" яким було затверджено “Положення про навчально-тренувальний відділ (центр) підготовки з надання медичної допомоги в екстремальних ситуаціях та оснащення для цих центрів"; наказ Міністерства охорони здоров'я України від 29.03.2017 № 346 “Про удосконалення підготовки 3 надання домедичної допомоги осіб, які не мають медичної освіти".

Відкритим залишається питання нормативного врегулювання питання щодо відповідальності рятувальника за неналежне надання ДМД постраждалому при ліквідації НС техногенного, природного та соціального характерів.

Ресурсна складова - це забезпечення рятувальників необхідними засобами для надання ДМД. Такими засобами є індивідуальна аптечка рятувальника та автомобільна аптечка. Комплектації аптечок визначають відповідні нормативноправові акти.

Але наказом ДСНС України від 14.12.2018 № 739 “Про забезпечення органів та підрозділів (формувань) цивільного захисту, закладів освіти сфери управління ДСНС лікарськими засобами, медичними виробами та медичною технікою поточного постачання" передбачено комплектація «Укладка медична для пожежного (аварійно - рятувального) розрахунку» в склад якої входять 
медикаменти які особи з немедичною освітою не мають права їх використовувати, що вносить додаткові складності щодо використання ліків при наданні ДМД постраждалим.

Тому нами було запропоновано доповнити даний наказ ДСНС «Індивідуальною аптечкою рятувальника», що на сьогодні залишається відкритим.

\section{Індивідуальна аптечка для пожежного (аварійно - рятувального) розрахунку} (розроблено автором)

\begin{tabular}{|c|c|c|}
\hline $\begin{array}{l}\text { № } \\
3 / \Pi\end{array}$ & Найменування лікарських засобів, медичних виробів & $\begin{array}{l}\text { Одиниця } \\
\text { виміру }\end{array}$ \\
\hline 1 & 2 & 3 \\
\hline 1 & $\begin{array}{l}\text { Плівка-клапан або маска клапан для проведення штучного } \\
\text { дихання «рот-до-рота» }\end{array}$ & штук \\
\hline 2 & $\begin{array}{l}\text { Пакет перев’язувальний медичний стерильний з кровоспинною } \\
\text { серветкою (типу бандаж) }\end{array}$ & штук \\
\hline 3 & Бинт стерильний 7 м х 14 см & упаковка \\
\hline 4 & Пов’язка для фіксації м’язів та суглобів & штук \\
\hline 5 & Протиопікова гідрогелева пов’язка & штук \\
\hline 6 & Серветка антисептична для обробки ран & штук \\
\hline 7 & Оклюзійна пов’язка з клапаном & штук \\
\hline 8 & Пластир фіксуючий в котушці на нетканій основі 5м х 2,5см & штук \\
\hline 9 & Джгут кровоспинний типу «Турнікет» & штук \\
\hline 10 & Джгут кровоспинний типу «Есмарха» & штук \\
\hline 11 & Рукавички медичні стерильні № 1 & пар \\
\hline 12 & Ножиці тактичні медичні & штук \\
\hline 13 & Покривало рятувальне ізотермічне & штук \\
\hline 14 & Маркер чорного кольору & штук \\
\hline 15 & Футляр або сумка & штук \\
\hline 16 & Опис вкладень & штук \\
\hline
\end{tabular}

Автомобільна аптечка, комплектація передбачена наказом Міністерства охорони здоров'я України від 07.07.1998 № 187 «Про затвердження переліків лікарських засобів у медичних аптечках транспортних засобів» та ДСТУ 39612000 зі змінами від 2013 № 2 які передбачають 2 варіанти аптечки. Наявність чинності цих двох документів вносить додаткові складності щодо використання ліків при наданні ДМД постраждалим.

Щодо кадрової складової, яка має забезпечувати надання ДМД населенню то iï можна розділити на дві складові: 
1. Інструктори з навчання ДМД, щодо підготовки інструкторів то на нашу думку вони регламентуються ось такими документами:

Постанова Кабінету Міністрів України від 21.11.2012 № 1115 “Про затвердження Порядку підготовки та підвищення кваліфікації осіб, які зобов'язані надавати домедичну допомогу”

У п.3. зазначено, що підготовка та підвищення кваліфікації проводяться на базі вищих медичних i фармацевтичних навчальних закладів I-IV рівня акредитації незалежно від форми власності та підпорядкування, навчальнотренувальних відділів центрів екстреної медичної допомоги та медицини катастроф, навчально-тренувальних відділів Товариства Червоного Хреста, інших навчально-тренувальних підрозділів (далі - установи), які провадять діяльність відповідно до законодавства про освіту за програмами, затвердженими МО3 i погодженими з МОНмолодьспортом.

У п.4. визначено, що установи, на базі яких проводяться підготовка та підвищення кваліфікації, за рівнем матеріально-технічного забезпечення i підготовки викладачів повинні відповідати вимогам, установленим МОНмолодьспортом.

В п.5. відповідальним за наукове та методологічне забезпечення підготовки та підвищення кваліфікації викладачів i викладачів-інструкторів установ призначено Український науково-практичний центр екстреної медичної допомоги та медицини катастроф.

Наказом Міністерства охорони здоров’я України від 18.03.2005 № 120 “Про організацію навчання медичних та немедичних працівників 3 надання медичної допомоги в екстрених ситуаціях”. Затверджено п.1.3. Уніфіковану програму підготовки викладачів 3 надання медичної допомоги в екстремальних ситуаціях. Окрім цього більше ніяких нормативно-керівних документів, що регламентують підготовку інструкторів $з$ домедичної підготовки не існує.

Але наявні документи, що закріплюють вимоги щодо кваліфікації майбутніх інструкторів є: наказ MO3 України від 29.03.2002 № 117 “Довідник кваліфікаційних характеристик професій працівників Випуск 78 “Охорона здоров'я”; Наказ МОЗ України від 09.08.2017 № 918 “Про внесення змін до Довідника кваліфікаційних характеристик професій працівників. Випуск 78 “Охорона здоров'я”. Дані кваліфікаційні вимоги до інструкторів можна викласти у вигляді таблиці 1: 
Кваліфікаційні вимоги до інструкторів з надання догоспітальної допомоги відповідно до

[Наказ Міністерства охорони здоров'я України від 09.08.2017 № 918 “Про внесення змін до Довідника кваліфікаційних характеристик професій працівників.

\section{Випуск 78 “Охорона здоров'я”] (опрацьовано автором)}

\begin{tabular}{|c|c|c|c|c|c|c|}
\hline $\begin{array}{l}\text { № } \\
\text { 3/ח }\end{array}$ & $\begin{array}{c}\text { Кваліфікаційна } \\
\text { категорія } \\
\text { інструктора }\end{array}$ & Освіта & $\begin{array}{l}\text { Підвищення } \\
\text { кваліфікації }\end{array}$ & $\begin{array}{c}\text { Посвідчення } \\
\text { наявність }\end{array}$ & $\begin{array}{c}\text { Стаж } \\
\text { роботи }\end{array}$ & Додаткові вимоги \\
\hline 1 & $\begin{array}{l}\text { Інструктор } \\
\text { надання } \\
\text { догоспітальної } \\
\text { допомоги вищої } \\
\text { кваліфікаційної } \\
\text { категорії: }\end{array}$ & $\begin{array}{l}\text { Вища освіта за } \\
\text { ступенем } \\
\text { молодшого } \\
\text { бакалавра з будь- } \\
\text { яких } \\
\text { спеціальностей } \\
\text { галузі з знань } \\
\text { "Охорона } \\
\text { здоров'я" }\end{array}$ & + & $\begin{array}{c}\text { Посвідчення про } \\
\text { присвоєння } \\
\text { (підтвердження) } \\
\text { вищої } \\
\text { кваліфікаційної } \\
\text { категорії з цієї } \\
\text { кваліфікації }\end{array}$ & $\begin{array}{l}\text { Білыше } \\
10 \text { років }\end{array}$ & - \\
\hline 2 & $\begin{array}{l}\text { Інструктор } \\
\text { надання } \\
\text { догоспітальної } \\
\text { допомоги } \\
\text { кваліфікаційної } \\
\text { категорії: }\end{array}$ & $\begin{array}{l}\text { Вища освіта за } \\
\text { ступенем } \\
\text { молодшого } \\
\text { бакалавра } 3 \text { будь- } \\
\text { яких } \\
\text { спеціальностей } \\
\text { галузі з знань } \\
\text { "Охорона } \\
\text { здоров'я" }\end{array}$ & + & $\begin{array}{c}\text { Посвідчення про } \\
\text { присвоєння } \\
\text { (підтвердження) I } \\
\text { кваліфікаційної } \\
\text { категорії з цієї } \\
\text { кваліфікації }\end{array}$ & $\begin{array}{l}\text { Більше } \\
7 \text { років }\end{array}$ & - \\
\hline 3 & $\begin{array}{l}\text { Інструктор } \\
\text { надання } \\
\text { догоспітальної } \\
\text { допомоги } \\
\text { кваліфікаційної } \\
\text { категорії: }\end{array}$ & $\begin{array}{l}\text { Вища освіта за } \\
\text { ступенем } \\
\text { молодшого } \\
\text { бакалавра з будь- } \\
\text { яких } \\
\text { спеціальностей } \\
\text { галузі } \quad \text { знань } \\
\text { "Охорона } \\
\text { здоров'я" }\end{array}$ & + & $\begin{array}{c}\text { Посвідчення про } \\
\text { присвоєння } \\
\text { (підтвердження) } \\
\text { II кваліфікаційної } \\
\text { категорії з цієї } \\
\text { кваліфікації }\end{array}$ & $\begin{array}{l}\text { Більше } \\
5 \text { років }\end{array}$ & - \\
\hline 4 & $\begin{array}{l}\text { Інструктор } \\
\text { надання } \\
\text { догоспітальної } \\
\text { допомоги (без } \\
\text { кваліфікаційної } \\
\text { категорії) }\end{array}$ & $\begin{array}{l}\text { Вища освіта за } \\
\text { ступенем } \\
\text { молодшого } \\
\text { бакалавра з будь- } \\
\text { яких } \\
\text { спеціальностей } \\
\text { галузі знань } \\
\text { "Охорона } \\
\text { здоров'я" }\end{array}$ & + & - & $\begin{array}{c}\text { Не } \\
\text { менше } 2 \\
\text { років }\end{array}$ & $\begin{array}{l}\text { 1. Наявність досвіду } \\
\text { практичної роботи } \\
\text { у сферах охорони } \\
\text { здоров'я, цивільної } \\
\text { безпеки, } \\
\text { соціального } \\
\text { захисту. } \\
2 . \quad \text { Наявність } \\
\text { сертифіката } \\
\text { закладу, } \\
\text { акредитованого } \\
\text { МОЗ України, про } \\
\text { проходження } \\
\text { навчання } \\
\text { програмою } \\
\text { підготовки } \\
\text { кваліфікацією } \\
\text { "Інструктор } \\
\text { надання } \\
\text { догоспітальної } \\
\text { допомоги". }\end{array}$ \\
\hline
\end{tabular}


За результатами аналізу кваліфікаційних вимог до інструкторів встановлено, що для Інструкторів 3 надання догоспітальної допомоги (без кваліфікаційної категорії) встановлено додаткову вимогу щодо наявності досвіду практичної роботи у сферах охорони здоров'я, цивільної безпеки, соціального захисту та обов'язкової наявності сертифіката закладу, акредитованого МОЗ України, про проходження навчання за програмою підготовки за кваліфікацією "Інструктор 3 надання догоспітальної допомоги".

2. Підготовлений персонал. Програма підготовки рятувальників 3 надання ДМД постраждалим при НС техногенного, природнього та соціального характерів було описано у другому розділі нашого дисертаційного дослідженнях. На нашу думку також до програми підготовки рятувальників 3 урахуванням світового досвіду доцільно включити процедуру сортування за алгоритмом «START».

Фінансово-економічна складова повинна визначити шляхи фінансування підготовки персоналу з ДМД та його заохочення за володіння такими навічками. Загалом ці дві складові у рятувальників та працівників аварійно-рятувальних служб фінансується рахунок кошт ДСНС України.

Не меш важливою $є$ інформаційна складова, завдання якої організовувати пропаганду серед населення та донесення необхідної інформації до співробітників. Такі цілі забезпечуються за рахунок роботи навчально методичних центрів системи ДСНС України, а саме інформування населення про всі НС по регіонах, за рахунок навчань які проводяться на їхніх базах. Також роботи сайту ДСНС України, куточків цивільного захисту і соціальних мереж які працюють на території нашої держави.

Для забезпечення адміністрування ДМД населенню та його розвитку необхідною є наукова складова, до якої відносяться:

- дослідження щодо удосконалення технологій та оснащення;

- імплементація світового досвіду.

Наукове супроводження необхідне на постійній основі тому, що розвиток країн світу не стоїть на місці, потрібно відстежувати кращі світові практики i рекомендації ВОО3.

Вище перелічені моменти слід віднести до ризико-утворюючих факторів в процесі підготовки фахівців з надання ДМД постраждалим, які узагальнено у таблиці 2

Таблиия 2.

Ризико-утворюючі фактори процесу підготовки фахівців з надання ДМД постраждалим (розроблено автором)

\begin{tabular}{|c|c|c|c|}
\hline $\begin{array}{c}\text { № } \\
\text { з/п }\end{array}$ & Назва фактору & Питомі відсотки & Рейтинг \\
\hline 1 & Сортування за алгоритмом «START» & $18 \%$ & 4 \\
\hline 2 & Атестація Інструкторів з домедичної & $30 \%$ & 1 \\
\hline
\end{tabular}




\begin{tabular}{|c|c|c|c|}
\hline & підготовки & $28 \%$ \\
\hline 3 & $\begin{array}{c}\text { Атестація рятувальників та } \\
\text { працівників аварійно-рятувальних } \\
\text { служб }\end{array}$ & $24 \%$ & 3 \\
\hline 4 & $\begin{array}{c}\text { Підготовка рятувальників та } \\
\text { працівників аварійно- рятувальних } \\
\text { служб }\end{array}$ & & \\
\hline
\end{tabular}

Отже якщо ми візьмемо всі наведені у таблиці 2 ризико-утворюючі факторів в процесі підготовки фахівців 3 надання ДМД постраждалим за 100\% то на першому місці у нас буде атестація Інструкторів з домедичної підготовки; на другому атестація рятувальників та працівників аварійно-рятувальних служб, на третьому підготовка рятувальників та працівників аварійно- рятувальних служб, на четвертому сортування за алгоритмом «START»

Адміністрування наданням ДМД постраждалим в зоні НС силами та підрозділами ОРС ЦЗ і мобільним формуваннями МК наведено у таблиці 3.

Таблиця 3.

\section{Адміністрування надання ДМД постраждалим в зоні НС силами та підрозділами ОРС ЦЗ і мобільним формуваннями МК (розроблено автором)}

\author{
Місце надання \\ допомоги
}

Вид допомоги

Надавачі

Обсяг

допомоги

Термін надання допомоги

Регламентація надання допомоги

Матеріально
Зона НC

На межі зони НС

Домедична допомога (Закон України Екстрена медична допомога (Закон "Про екстрену медичну допомогу") України "Про екстрену медичну допомогу")

Рятувальники аварійно-рятувальних Бригади Е(Ш)МД, бригади СМК I служб, працівники державної черги, мобільні медичні пункти пожежної охорони, поліцейські ДСНС, МГ ДСНС

Вступне сортування, базова Медичне сортування, невідкладна підтримка життя, професійна медична допомога, медична підтримка життя.

евакуація за показами

До 60 хв. (з урахуванням проведення 0-72 год (з урахуванням пошуковопошуково-рятувальних робіт)

рятувальних робіт)

Наказ МО3 України від 16.06.2014 № Наказ МО3 України від 05.06.2016 № 398 "Про затвердження порядків 1269 "Про затвердження та надання домедичної допомоги особам впровадження медико-технологічних при невідкладних станах" документів зі стандартизації \{Із змінами, внесеними згідно з наказом екстреної медичної допомоги" МОЗ Украӥни від 08.10.2018 № 1833\}

Наказ МОЗ України від 29.03.2017 №

346 "Про удосконалення підготовки

з надання домедичної допомоги осіб, які не мають медичної освіти"

ДСТУ 3691-2000 “Аптечка медична Наказ МОЗ України від 10.08.2001 № 
технічне забезпечення
Особливості підготовки надавачів допомоги автомобільна. Загальні вимоги" Наказ ДСНС України від 14.12.2018 № 739 "Про забезпечення органів та підрозділів (формувань) цивільного захисту, закладів освіти сфери управління ДСНС лікарськими засобами, медичними виробами та медичною технікою поточного постачання"
331 "Про затвердження

номенклатури резервів лікарських засобів, виробів медичного призначення та медичного обладнання для запобігання та ліквідації медико-санітарних наслідків надзвичайних ситуацій техногенного і пиродного характеру $\{13$ змінами, внесеними згідно 3 Наказом МO3 від 09.09.2006 № 613 '"

Наказ МОЗ України від 07.12.2012 № 1020 "Про внесення змін до наказу Міністерства охорони здоров'я України від 29.08.2008 № 500"

Постанова КМУ від 30.09.2015 № 775 "Про затвердження Порядку створення та використання матеріальних резервів для запобігання i ліквідації наслідків надзвичайних ситуацій”

Наказ МОЗ України від 19.05.2020 № 1167 "Про затвердження Примірного табеля матеріально-технічного оснащення відділень екстреної (невідкладної) медичної допомоги" Наказ МОЗ України від 05.06.2020 № 1311 "Про затвердження Примірного табеля оснащення структурних підрозділів системи екстреної медичної допомоги "

п.1 ст.12 Закану України “Про п.п. 7,8,9 ст. 48 “Атестація аварійноекстрену медичну допомогу” рятувальних служб та рятувальників" п.п.4, п.2; п.п.24, п.4 Постанови КМ Кодекс цивільного захисту України

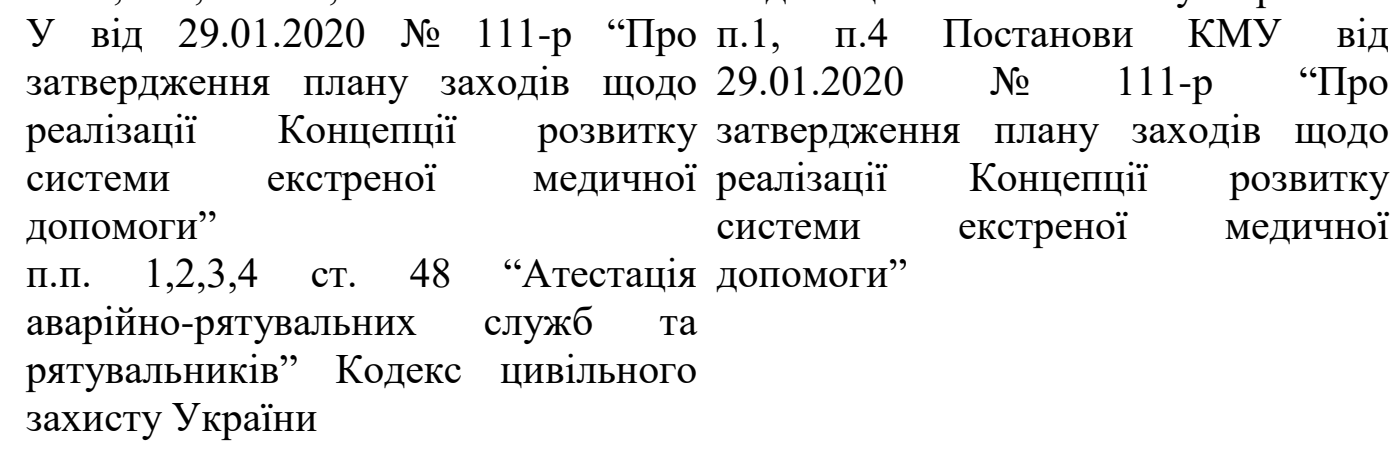

Аналізуючи дані, що наведені в таблиці 3 можна стверджувати, що адміністрування надання ДМД залежить, в першу чергу, від місця ії надання. В зоні НС відповідно до Закону України "Про екстрену медичну допомогу" надається тільки ДМД рятувальниками АРС, працівниками державної пожежної охорони та поліцейськими. Обсяг допомоги включає: первинне сортування, 
базова підтримка життя, також за наявності фельдшера або лікаря буде проведення професійної підтримки життя. 3 урахуванням проведення пошуковорятувальних робіт термін надання ДМД повинен складати до 60 хвилин. У зоні НС надання ДМД та оснащення регламентується такими керівними документами $[14,15]$. Що стосується підготовки осіб які надаватимуть ДМД в зоні НС то вона регламентується такими нормативними документами п.1 ст.12 [16], п.4, п.2; п.п.24, п.4 [17], п.п. 1,2,3,4 ст. 48 “Атестація аварійно-рятувальних служб та рятувальників" [1].

Що стосується наступної зони, на межі НС, то там відповідно до Закону України “Про екстрену медичну допомогу" надається тільки ЕМД, бригадами Е(Ш)МД, бригадами СМК I черги, мобільним медичним пунктом ДСНС та МГ ДСНС. Також і відрізняється час з урахуванням пошуково-рятувальних робіт він складає від 0 до 72 годин. На межі зоні НС надання ЕМД та оснащення регламентується такими керівними документами $[18,19,20,21]$. Що стосується підготовки осіб які надаватимуть ЕМД на межі зони НС то вона регламентується такими нормативними документами п.п. 7,8,9 ст. 48 “Атестація аварійнорятувальних служб та рятувальників" [1], п.1, п.4 [17].

Формування наступних адміністративно правових засад викладено у таких законодавчих та нормативних документах а саме: статті 6 абзацу двадцятого частини першої Закону України “Про екстрену медичну допомогу”, п. 3 Постанови Кабінету Міністрів України від 21.11.2012 № 1121 "Про затвердження Порядку взаємодії закладів охорони здоров'я що входять до системи екстреної медичної допомоги, 3 аварійно-рятувальними службами та підрозділами центральних та інших органів виконавчої влади, органів влади Автономної Республіки Крим, органів місцевого самоврядування під час виникнення надзвичайних ситуацій та ліквідації їх наслідків”, п-тів. 47-50 Постанови Кабінету Міністрів України від 09.01.2014 № 11 “Положення про єдину державну систему цивільного захисту”, п. 7 Постанови Кабінету Міністрів України від 25.03.2015 № 267 “Положення про Міністерство охорони здоров'я України”, та п. 8 Постанови Кабінету Міністрів України від 16.12. 2015 № 1052 “Положення про Державну службу України з надзвичайних ситуацій”, та 3 метою організація взаємодії між ДСНС та МO3, під час виконання ними спільних завдань з ліквідації медикосанітарних наслідків НС у різних режимах функціонування СДСЦЗ, здійснюється згідно спільного наказу МВС/MO3 від 03.04.2018 “Про затвердження Інструкції щодо організації взаємодії між Державною службою України 3 надзвичайних ситуацій i Міністерством охорони здоров'я України в разі виникнення надзвичайних ситуацій”.

Метою даної взаємодії є забезпечення ефективного використання медичного 
персоналу, спеціалізованого санітарного транспорту, медичних виробів, лікарських засобів, закладів охорони здоров'я для рятування життя та збереження здоров'я людей під час ліквідації медико-санітарних наслідків НС.

Взаємодія організовується між «Оперативно-черговою службою державного центру управління в надзвичайних ситуаціях ДСНС» та оперативнодиспетчерським відділом ДЗ «УНПЦ ЕМД та МК».

Основними принципами взаємодії є:

- єдині підходи до реалізації державної політики у сфері попередження та ліквідації НС, охорони здоров'я населення і профілактики захворювань;

- пріоритет збереження життя і здоров'я населення при виникненні та під час ліквідації НС;

- єдині підходи і критерії під час прогнозування та оцінювання медикосанітарної обстановки за різних НС, визначення можливостей рятувальних i медичних підрозділів, формувань та закладів [22].

Отже режим повсякденного функціонування: загальні заходи - направлення до складу координаційних комісій ДСМК та робочих груп представників ДСНС та MO3 України. Окремими заходами які виконує кожна структура на цьому режимі є з боку ДСНС України: здійснення навчання особового складу аврійнорятувальних підрозділів навичкам надання ДМД постраждалим при НС, також належне утримання мобільного шпиталю, здійснення підготовки та підвищення кваліфікації медичних працівників за напрямом “Медицина невідкладних станів”, здійснення перевірки готовності органів управління та сил ЦЗ до медичного та біологічного захисту населення при НС. 3 боку МО3 України: розроблення та затвердження плану реагування на НС для ліквідації медико-санітарних наслідків наслідків НС, розробка протоколів надання ДМД та ЕМД постраждалим при НС, проводити постійний моніторинг за навколишнім середовищем, що впливає на стан здоров'я людини, також на постійній основі створює відомчий матеріальний резерв лікарських засобів та медичних виробів, також організовує підготовку фахівців які відповідають за функціональну підсистему та спеціалізовані служби цивільного захисту.

Наступний режим підвищеної готовності: загальні заходи - формування оперативних груп для виявлення причин погіршення обстановки в районі можливого виникнення НС, складання загального плану термінових заходів для попередження (зменшення) медико-санітарних наслідків НС. Окремими заходами які виконує кожна структура на цьому режимі є з боку ДСНС України: надання інформації про загрози виникнення НС до оперативно-диспечерського віддділу ДЗ “УНПЦ ЕМД та МК МОЗ України” також інформує про прийняті рішення 3 підготовки до ліквідації наслідків НС. 3 боку МОЗ України: надає інформацію ДСНС щодо прогнозу медико-санітарних наслідків НС також розрахунок сил $\mathrm{i}$ 
засобів та спеціалізованої служби ЦЗ які створює MO3 України, також надає інформацію щодо установ та закладів охорони здоров'я які планують залучити для ліквідації медико-санітарних наслідків НС, визначаються сили та засоби що можуть бути залучені з інших регіонів для ліквідації медико-санітарних наслідків НC, організовує та здійснює санітарно-гігієнічні та протиепідемічні заходи в районах що межують із зоною НС, комплектує медичними працівниками до повного штату мобільний шпиталь ДСНС України.

Останній третій режим НС: загальні заходи - створення спеціальної комісії 3 ліквідації НС зі складу ДСНС і МОЗ України, надаються пропозиції щодо ліквідації медико-санітарних наслідків НС, також визначаються спільні сили та засоби які будуть задіяні для ліквідації наслідків НС, продовжується постійний обмін інформацією про перебіг ліквідації НС. Окремими заходами які виконує кожна структура на цьому режимі є з боку ДСНС України: при надходженні інформації через службу державного центру управління в НС ДСНС інформує MO3 про виникнення НC та їі розвиток, також про рішення які приймаються 3 ліквідації наслідків НС, забезпечує надання ДМД постраждалим в зоні НС та за межами, здійснює переміщення постраждалих у безпечну зону та передачу цих постраждалих працівникам MO3 України для подальшого лікування, здійснює заходи з ліквідації наслідків НС. 3 боку МО3 України: направляє свої працівників до штабу ліквідації наслідків НС для оцінки медико-санітарних наслідків, також розробляє рекомендації щодо заходів 3 їх ліквідації потім через оператинодиспечерські служби надає ДСНС інформацію, щодо обсягів та характеру медикосанітарних наслідків НС, організовують та надають кваліфіковану ЕМД постраждалим при НС за межами зони НС також здійснює медичне забезпечення населення під час евакуації в районі НС та в місцях їх розміщення, забезпечує поповнення лікарськими засобами та медичними виробами заклади охорони здоров'я які беруть участь в аварійно-рятувальних роботах.

Висновок. Сформульовано авторську дефініцію терміну «адміністрування надання ДМД постраждалим внаслідок НС» як «організацію надання допомоги постраждалим внаслідок НС, які знаходяться в умовах небезпеки та мають такий стан здоров'я, що потребує негайного проведення заходів, спрямованих на підтримку базових функцій життя, без застосування лікарських засобів, професіоналами, які пройшли відповідну підготовку та за своїми посадовими обов'язками зобов'язані надавати даний вид допомоги в екстремальних умовах».

Таким чином адміністрування процесу надання ДМД постраждалим внаслідок НС в умовах великого скупчення людей може бути інтегрованою сукупністю методів державного управління, які передбачають систему заходів законодавчого, виконавчого i контрольного характеру, що здійснюється державними органами в сфері медичного захисту населення 3 метою запобігання 
НC та пом'якшення їх наслідків. В цьому контексті принциповим 3 наукової та практичної та практичної точки зору є дослідження механізмів взаємодії органів державного управління при організації ліквідації медико-санітарних наслідків НС.

\section{Лimepamypa:}

1. Кодекс цивільного захисту України: Закон України від 02.10.2012 р. № 5403-VI. URL: http://zakon4.rada.gov.ua/laws/show/5403-17/print1360003604244711

2.Шостак Л. Й. Міжнародний досвід організації ліквідації наслідків надзвичайних ситуацій / Л. Й. Шостак // Науковий вісник Академії муніципального управління. Серія : Управління. - 2011. - Вип. 4. - С. 368-378. - Режим доступу: http://nbuv.gov.ua/UJRN/Nvamu_upravl_2011_4_51.

3. Медичний та біологічний захист за умов надзвичайних ситуацій: навчальний посібник. Близнюк М.Д., Волянський П.Б., Гафарова М.Т., Гур'єв С.О., Долгий М.Л., Іскра Н.I., Крилюк В.О., Кузьмін В.Ю., Матяш В.І., Сацик С.П., Терент'єва А.В. - Х.: ФОП Панов А.М., 2016. $-324 \mathrm{c}$.

4. Виживання в умовах надзвичайних ситуацій: практичний посібник/Волянський П.Б., Барило О.Г., Гур'єв С.О., Долгий М.Л., Євсюков О.П., Іскра Н.І., Михайлов В.М., Потеряйко С.П., Терент'єва А.В. Х.: ФОП Панов А.М., 2016.-189 с.

5. Макаренко А.М., Толкунов I.О., Система невідкладної медичної допомоги США: особливості організації та підготовки фахівців / А.М. Макаренко, І.О. Толкунов// Тези доповідей науково-практичного семінару «Запобігання надзвичайним ситуаціям і їх ліквідація» (07 лютого 2018 року). - Харків: Національний університет цивільного захисту України, 2018 C. $41-44$

6. Реагування на надзвичайні ситуації / Барило О.Г., Волянський П.Б., Гур'єв С.О., Долгий М.Л., Євсюков О.П., Михайлов В.М., Іскра Н.І., Потеряйко С.П., Терент'єва А.В., Ткаченко О.В. - К.: Вид-во «Бланк-Прес». 2014. - 208c.

7. Лєрмонтова Ю. О. Державне управління екстреною медичною допомогою при надзвичайних ситуаціях в закордонних країнах / Ю.О. Лєрмонтова // Державне управління та місцеве самоврядування: зб. наук. Праць. - Дніпропетровськ : Вид-во ДРІДУ НАДУ, 2012. - №4 (15) - C.191-199.

8. Адамкевич-Герод Барбара, Мадовіч Ярослав. Система освіти медичних рятувальників у Польщі (адаптація тексту: Крилюк B.O., Кузьмінський I.B.). URL: http://emergency.in.ua/component/content/article/13-st2013/84-st-3-8 (дата звернення: 01.07.2020)

9. Михайлов В.М. Роль підрозділів національної пожежно-рятувальної системи у функціонуванні державної системи медичної допомоги в Польщі. Вісник наиіонального університету иивільного захисту України. Серія Державне управління. 2016. Вип. 2. С. 309-316. URL: htpp:////nuczu.edu.ua/sciencearchive/PublicAdministration/vol5/Visnyk_NUCZU_43_2016_ 2(5).pdf (дата звернення: 01.07.2020).

10. Олійник В. О. Особливості організації служби швидкої медичної допомоги в Польщі. Медична освіта. 2013. № 3. С. 71-73.

11. Пилипець А. Я., Пилипець Я. Д. Світові моделі екстреної медичної допомоги: яка придатна до впровадження в Україні. URL: http://rocemd.at.ua/index/svitovi_modeli_ekstrenoji_ medichnoji_dopomogi_jaka_pridatna_do_vprovadzhennja_v_ukrajini/0-44 (дата звернення: 01.07.2020).

12. Хоменко К. П. Порівняльний аналіз підготовки лікарів у Польщі та Україні. 
Педагогічні науки: теорія, історія, інноваційні технології. 2015. № 8 (52). С. 226-233.

13. Публічне управління : термінол. слов. / уклад. : В. С. Куйбіда, М. М. Білинська, О. М. Петроє та ін. ; за заг. ред. В. С. Куйбіди, М. М. Білинської, О. М. Петроє. - Київ : НАДУ, 2018. - 224 c.

14. Наказ МО3 України від 16.06.2014 № 398 “Про затвердження порядків надання домедичної допомоги особам при невідкладних станах" \{ІІ змінами, внесеними згідно з наказом МОЗ України від 08.10.2018 № 1833\};

15. Наказ Державної служби України з надзвичайних ситуацій від 14.12.2018 № 739 “Про забезпечення органів та підрозділів (формувань) цивільного захисту, закладів освіти сфери управління ДСНС лікарськими засобами, медичними виробами та медичною технікою поточного постачання"

16. Закон України від 05.07.2012 p. №5081-VI “Про екстрену медичну допомогу”

17. Постанови Кабінету Міністрів України від 29.01.2020 № 111-р “Про затвердження плану заходів щодо реалізації Концепції розвитку системи екстреної медичної допомоги”

18. Наказ Міністерства охорони здоров'я України від 05.06.2016 № 1269 “Про затвердження та впровадження медико-технологічних документів зі стандартизації екстреної медичної допомоги"

19. Постанова Кабінету Міністрів України від 30.09.2015 № 775 "Про затвердження Порядку створення та використання матеріальних резервів для запобігання і ліквідації наслідків надзвичайних ситуацій”

20. Наказ Міністерства охорони здоров'я України від 19.05.2020 № 1167 "Про затвердження Примірного табеля матеріально-технічного оснащення відділень екстреної (невідкладної) медичної допомоги"

21. Наказ Міністерства охорони здоров'я України від 05.06.2020 № 1311 “Про затвердження Примірного табеля оснащення структурних підрозділів системи екстреної медичної допомоги"

22. Наказ МВC/MO3 03.04.2018 p. № 275/600 “Про затвердження Інструкції щодо організації взаємодії між Державною службою України 3 надзвичайних ситуацій i Міністерством охорони здоров'я України в разі виникнення надзвичайних ситуацій”

\section{References:}

1. Kodeks cyviljnogho zakhystu Ukrajiny: Zakon Ukrainy (2012, October 02) № 5403-VI. URL: http://zakon4.rada.gov.ua/laws/show/5403-17/print1360003604244711 .

2. Shostak L. Y. (2011) Mizhnarodnyi dosvid orhanizatsii likvidatsii naslidkiv nadzvychainykh sytuatsii [International experience in organizing the elimination of the consequences of emergencies]. Naukovyi visnyk Akademii munitsypalnoho upravlinnia. Seriia : Upravlinnia, 4, 368-378 URL http://nbuv.gov.ua/UJRN/Nvamu_upravl_2011_4_51 [in Ukranian]

3. Blyzniuk M.D., Volianskyi P.B., Hafarova M.T., Huriev S.O., Dolhyi M.L. "et al.” (2016) Medychnyi ta biolohichnyi zakhyst za umov nadzvychainykh sytuatsii: navchalnyi posibnyk [Medical and biological protection in emergencies: a textbook]. Kharkiv: FOP Panov A.M. [in Ukranian]

4. Volianskyi P.B., Barylo O.H., Huriev S.O., Dolhyi M.L., Yevsiukov O.P., "et al.” (2016) Vyzhyvannia $v$ umovakh nadzvychainykh sytuatsii: praktychnyi posibnyk [Survival in emergencies: a practical guide] Kharkiv: FOP Panov A.M. [in Ukranian]

5. Makarenko A.M., Tolkunov I.O., (2018) Systema nevidkladnoi medychnoi dopomohy SShA: osoblyvosti orhanizatsii ta pidhotovky fakhivtsiv [The US emergency medical care system: features of 
organization and training] Proceedings from MIIM '18: Naukovo-praktychnoho seminaru «Zapobihannia nadzvychainym sytuatsiiam i yikh likvidatsiia» - Scientific-practical seminar "Prevention of emergencies and their elimination" (pp. 41-44). Kharkiv: Natsionalnyi universytet tsyvilnoho zakhystu Ukrainy [in Ukranian]

6. Barylo O.H., Volianskyi P.B., Huriev S.O., Dolhyi M.L., Yevsiukov O.P. “et al.” (2014) Reahuvannia na nadzvychaini sytuatsii [Emergency response] Kyiv: Vyd-vo «Blank-Pres» [in Ukranian]

7. Liermontova Yu. O. Derzhavne upravlinnia ekstrenoiu medychnoiu dopomohoiu pry nadzvychajnykh sytuatsiiakh v zakordonnykh krainakh / Yu.O. Liermontova // Derzhavne upravlinnia ta mistseve samovriaduvannia: zb. nauk. Prats'. - Dnipropetrovs'k : Vyd-vo DRIDU NADU, 2012. №4 (15) - S.191-199.

8. Adamkievich-Herod, Barbara, Madovich, Yaroslav. (2013). Systema osvity medychnykh riatuval'nykiv u Pol'schi [The system of education of medical rescuers in Poland]. URL: http://emergentsy.in.ua/tsomponent/tsontent/artitsle/13-st2013/84-st-3-8 [in Ukrainian]

9. Mykhajlov, V.M. (2016). Rol pidrozdiliv natsionalnoi pozhezhno-riatuvalnoi systemy u funktsionuvanni derzhavnoi systemy medychnoi dopomohy $\mathrm{v}$ Polschi [The role of the units of the national $\square$ re and rescue system in the functioning of the state system of medical care in Poland]. Visnyk Natsionalnoho universytetu tsyvilnoho zakhystu Ukrainy. Seriia: Derzhavne upravlinnia, issue 2, 309-316. URL: http://nuczu.edu.ua/sciencearchive/PublicAdministration/vol5/Visnyk_NUCZU_ 43_2016_2(5).pdf [in Ukrainian].

10. Olijnyk, V.O. (2013). Osoblyvosti orhanizatsii sluzhby shvydkoi medychnoi dopomohy v Polschi [Features of the organization of the ambulance service in Poland]. Medychna osvita, 3, 71-73 [in Ukrainian].

11. Pylypets, A.Ya., Pylypets, Ya.D. Svitovi modeli ekstrenoi medychnoi dopomohy: iaka prydatna do vprovadzhennia v Ukraini [World Emergency Medical Models: Which is Applicable to Implementation in Ukraine]. URL: http://rocemd.at.ua/index/svitovi_modeli_ekstrenoji_medichnoji_ dopomogi_jaka_pridatna_do_vprovadzhennja_v_ukrajini/0-44 [in Ukrainian].

12. Khomenko, K.P. (2015). Porivnialnyj analiz pidhotovky likariv u Polschi ta Ukraini. [Comparative analysis of training of doctors in Poland and Ukraine]. Pedahohichni nauky: teoriia, istoriia, innovatsijni tekhnolohii, 8 (52), 226-233 [in Ukrainian].

13. V. S. Kuibida, M. M. Bilynska, O. M. Petroie "et al." (2018) Publichne upravlinnia : terminolohichnyi slovnyk [Public administration: a glossary] Kyiv : NADU [in Ukrainian]

14. Nakaz Ministerstva oxorony zdorov'ya Ukrayiny Pro zatverdzhennya poryadkiv nadannya domedychnoyi dopomogy osobam pry nevidkladnyx stanax: pryiniaty 16 June 2014 roku № 398 [Order of the Ministry of Health of Ukraine On approval of procedures for providing home care to persons in emergencies dated June 16 2014, № 398 ]. zakon.rada.gov.ua. Retrieved from https://zakon.rada.gov.ua/laws/show/z0750-14\#Text [in Ukrainian].

15. Nakaz The State Emergency Service of Ukraine Pro zabezpechennia orhaniv ta pidrozdiliv (formuvan) tsyvilnoho zakhystu, zakladiv osvity sfery upravlinnia DSNS likarskymy zasobamy, medychnymy vyrobamy ta medychnoiu tekhnikoiu potochnoho postachannia: 14 December 2018 № 739 [About providing of bodies and divisions (formations) of civil protection, educational institutions of sphere of management of DSNS with medicines, medical devices and medical equipment of current supply dated December 14 2018, № 739]. Retrieved from https://www.dsns.gov.ua/files/2020/10/13/3/549-09.10.2020.pdf [in Ukrainian].

16. Zakon pro ekstrenu medychnu dopomohu, 2012 (Verkhovna Rada Ukrayiny) [Law on 
Emergency Medical Care, 2012 (Verkhovna Rada of Ukraine)]. Ofitsiynyy sayt Verkhovnoyi Rady Ukrayiny [Official site of the Verkhovna Rada of Ukraine] <https://zakon.rada.gov.ua/laws/show/5081-17> (2021, April, 14). [in Ukrainian].

17. Postanova Kabinetu Ministriv Ukrayiny Pro zatverdzhennia planu zakhodiv shchodo realizatsii Kontseptsii rozvytku systemy ekstrenoi medychnoi dopomohy, 2020 (Kabinet Ministriv Ukrayiny) [On approval of the action plan for the implementation of the Concept of development of the emergency medical care system, 2020 (Cabinet of Ministers of Ukraine)]. Ofitsiynyy sayt Kabinetu Ministriv Ukrayiny [Official site of the Cabinet of Ministers of Ukraine] https://www.kmu.gov.ua/npas/pro-zatverdzhennya-planuzahodiv-shchom290120do-realizaciyi-koncepciyi-rozvitku-sistemi-ekstrenoyi-medichnoyi-dopomogi (2021, April, 14). [in Ukrainian].

18. Nakaz Ministerstva oxorony zdorov'ya Ukrayiny Pro zatverdzhennya poryadkiv nadannya domedychnoyi dopomogy osobam pry nevidkladnyx stanax: pryiniaty 05 June 2016 roku № 1269 [About the statement and introduction of medical and technological documents on standardization of emergency medical care dated June 05 2016, № 1269 ]. zakon.rada.gov.ua. Retrieved from https://moz.gov.ua/article/ministrymandates/nakaz-moz-ukraini-vid-05062019--1269-pro-zatverdzhennjata-vprovadzhennja-medikotehnologichnih-dokumentiv-zi-standartizacii-ekstrenoi-medichnoi-dopomogi [in Ukrainian].

19. Postanova Kabinetu Ministriv Ukrayiny Pro zatverdzhennia Poriadku stvorennia ta vykorystannia materialnykh rezerviv dlia zapobihannia i likvidatsii naslidkiv nadzvychainykh sytuatsii, 2015 (Kabinet Ministriv Ukrayiny) [About the statement of the Order of creation and use of material reserves for prevention and liquidation of consequences of emergency situations, 2015 (Cabinet of Ministers of Ukraine)]. Ofitsiynyy sayt Kabinetu Ministriv Ukrayiny [Official site of the Cabinet of Ministers of Ukraine] https://zakon.rada.gov.ua/laws/show/775-2015-\%D0\%BF\#Text (2021, April, 14). [in Ukrainian].

20. Nakaz Ministerstva oxorony zdorov'ya Ukrayiny Pro zatverdzhennia Prymirnoho tabelia materialno-tekhnichnoho osnashchennia viddilen ekstrenoi (nevidkladnoi) medychnoi dopomohy: pryiniaty 19 May 2020 № 1167 [Order of the Ministry of Health of Ukraine About the statement of the Sample report card of material and technical equipment of departments of emergency (emergency) medical care dated May 19 2020, № 1167 ]. zakon.rada.gov.ua. Retrieved from https://moz.gov.ua/article/ministry-mandates/nakazmoz-ukraini-vid-19052020--1167-pro-zatverdzhennja- primirnogo-tabelja-materialno-tehnichnogoosnaschennja-viddilen-ekstrenoi-nevidkladnoi-medichnoi-dopomogi [in Ukrainian].

21. Nakaz Ministerstva oxorony zdorov'ya Ukrayiny Pro zatverdzhennia Prymirnoho tabelia osnashchennia strukturnykh pidrozdiliv systemy ekstrenoi medychnoi dopomohy: pryiniaty 05 June 2020 № 1311 [Order of the Ministry of Health of Ukraine About the statement of the Sample report card of equipment of structural divisions of system of emergency medical care June 05 2020, № 1311]. zakon.rada.gov.ua. Retrieved from https://moz.gov.ua/article/ministry-mandates/nakaz-moz-ukraini-vid-05062020--1311-prozatverdzhennja-primirnogo-tabelja osnaschennja-strukturnih-pidrozdiliv-sistemi-ekstrenoi-medichnoidopomogi [in Ukrainian].

22. Nakaz Ministerstvo vnutrishnikh sprav Ukrainy/Ministerstva oxorony zdorov'ya Ukrayiny Pro zatverdzhennia Instruktsii shchodo orhanizatsii vzaiemodii mizh Derzhavnoiu sluzhboiu Ukrainy $\mathrm{z}$ nadzvychainykh sytuatsii i Ministerstvom okhorony zdorovia Ukrainy v razi vynyknennia nadzvychainykh sytuatsii: pryiniaty 03 April 2018 № 275/600 [Order of the Ministry of Internal Affairs of Ukraine /Ministry of Health of Ukraine On approval of the Instruction on the organization of interaction between the State Service of Ukraine for Emergencies and the Ministry of Health of Ukraine in case of emergencies April 03 2018, № 275/600]. zakon.rada.gov.ua. Retrieved from https://zakon.rada.gov.ua/laws/show/z0479-18\#Text [in Ukrainian]. 